\title{
Short Communication: \\ Ethnobotanical study of Lygodium circinnatum and its utilization in crafts weaving in Indonesia
}

\author{
MULYATI RAHAYU ${ }^{1, \vartheta}$, EMMA SRI KUNCARI ${ }^{1, \vee \vartheta}$, MAHDAWIA ${ }^{2}$, MARWAN SETIAWAN ${ }^{1}$ \\ ${ }^{1}$ Research Center for Biology, Indonesian Institute of Sciences. Cibinong Science Center, J1 Raya Jakarta-Bogor Km. 46, Cibinong, Bogor 16911, West \\ Java, Indonesia. Tel./fax.: +62-21-8765066, "email: mulyati_r@yahoo.com; ‘"emmakuncari@gmail.com. \\ ${ }^{2}$ Universitas Tadulako. Jl. Soekarno-Hatta Km. 9, Tondo, Mantikulore, Palu 94148, Central Sulawesi, Indonesia
}

Manuscript received: 11 November 2019. Revision accepted: 18 January 2020.

\begin{abstract}
Rahayu M, Kuncari ES, Mahdawia, Setiawan M. 2020. Short Communication: Ethnobotanical study of Lygodium circinnatum and its utilization in crafts weaving in Indonesia. Biodiversitas 21: 617-621. Lygodium circinnatum (Burm.f.) Swartz, locally known as ketak, is a species of ferns that is currently widely used as raw material for making woven artifacts. In Indonesia, the center of L. circinnatum handicrafts, among others, is the island of Bali, Lombok and the city of Kendari. A variety of products are in great demand, not only by domestic tourists but also by foreign tourists. Cultivation of $L$. circinnatum has not been undertaken effectively, therefore raw material supply is still from wild populations. This ethnobotanical study conducted to review the traditional use of L. circinnatum and its cultivation efforts. This is essential as the use value of the L. circinnatum is increasing and also to ensure the continued availability of raw materials.
\end{abstract}

Keywords: Ethnobotany, ketak, Lygodium circinnatum, woven crafts

\section{INTRODUCTION}

In Indonesia, various species of plants are used as raw materials for industries, including making of woven crafts. Lygodium circinnatum (Burm. f.) Swartz, commonly called ketak, is a fern species widely used as a raw material for making of woven crafts which are popular in many countries, including Indonesia (Heyne 1987).

Fiber is very useful for human life. The usefulness of fiber, among others, as a woven raw material. Fiber can come from living things like animals and plants. Vegetable fibers can come from roots, stems, leaves, fruits or seeds. Lygodium circinanntum (Burm.f.) Swartz is one of the fiber-producing plants as raw material for woven crafts (Darmayanti 2014).

Rice (2016) found that local woven crafts are generally inherited from generation to generation, created from a historical concept or folklore as outlined in various types of art. The weaving craft is one product that is currently known among art lovers. This craft is known for its durability and flexibility, which process is conventional and often combined with other plants such as bamboo or rattan (Setiawan et al. 2014; Gusmawarni et al. 2019). It is also known as "hata" in Pangandaran District, and included among Non-Timber Forest Product commodities (Suyarno 2019). In Bali and Lombok islands, fabric woven from $L$. circinnatum has a high artistic value.

The Lygodium genus is a group of nails that propagates and always propagates in other plants. This genus is very different from other species of ferns because it has rhizome roots that spread above the ground and can only live in an open area as a light demanding plant (Shinta et al., 2012)

The products woven from $L$. circinnatum appear similar to those of rattan. The stems of $L$. circinnatum, which are used for weaving, have a fine, tough and strong texture when compared to other handicraft raw materials, such as rattan, bamboo and pandanus. This makes the $L$. circinnatum woven products superior and more priced than those made from other raw materials.

Due to its increasing public interest and also export market potential, this craft product, is considered to be one of the supporting economic sources of tourism. But, unfortunately, cultivation of this fern to meet the needs for raw materials has not been carried out effectively.

The objective of this ethnobotanical study is to provide an overview the use of L. circinnatum as the important raw material for woven crafts. In addition, other benefits of $L$. circinnatum is also presented so that they can be used as reference materials for further development of this traditional activity.

\section{MATERIALS AND METHODS}

The method used in this study refers to Martin (1995) and Cunningham (2001) with modifications including interviews, herbarium observations and artifacts.

Information was gathered by direct observations at the center of handicrafts located in Beleke Village of Lombok Island, Karang Asem of Bali Island and Kendari city of Southeast Sulawesi; interviews with the craftsmen engaged in L. circinnatum weaving; examination of herbarium 
specimens at Herbarium Bogoriense (BO), Botany Division, Research Center for Biology, Indonesian Institute of Science (LIPI), Bogor, Indonesia, and observation of artifact collections at the National Museum of Indonesian Natural History, Bogor, Indonesia. Data recorded from weaving centers included the locations of obtaining raw materials, the process of making woven crafts and the locations of sale; from the herbarium specimens regarding the collector's name, year of acquisition, specimen collection location, habitat, and use; and from the artifact collection centers include the name of the artifact, the location of its acquisition and its use. In addition, relevant information was collected from related published literature.

\section{RESULTS AND DISCUSSION}

Lygodium circinnatum, earlier included in the family Schizaeaceae (Praptosuwiryo, 2003), but currently is a member of Lygodiaceae (Madeira et al. 2008). Synonyms of this species include $L$. basilanicum Christ; $L$. dichotomum (Cav.) Sw. and L. pedatum (Burm.f.) Sw. (Rugayah et al. 2015). Globally, Lygodium genus consists of 40 species, mostly found in Southeast Asia and Central America. L. circinnatum is distributed from Sri Lanka, northeast India to southern China, continues to Southeast Asia to the Solomon Islands and Vanuatu (Praptosuwiryo 2003).

In Indonesia, L. circinnatum is known by several local names, such as "paku kawat" (Shinta et al. 2012), "pakis rambat", "pakis ata" (Javanese), "paku ata" (Sundanese), "ata" (Balinese), "masem" (Minahasa), "raga-raga" (Makasar), caweng (Bugis), "mongodo" (Halmahera), "gomoho" (Ternate) and "gomongo" (Tidore) (Heyne 1987), "ribu-ribu" (West Kalimantan) (Hasibuan et al. 2016). Some of the local names are indicative of certain features of this plant, for example, the name "paku kawat" is given because the plant is strong like a wire, "pakis rambat" indicates the nature of propagation, and "riburibu" refers to the production of large number of spores reaching thousands.

Lygodium circinnatum (Figure 1) is a terrestrial fleshy fern that has a short rhizome, which spreads on the ground. The stem is generally called rachis, the length can reach up to10 $\mathrm{m}, 2-5 \mathrm{~mm}$ in diameter; sterile rachis branching like a fork (dichotomous), brownish green; fertile rachis branching also like a fork (dichotomous), brownish green, the direction of rotation to the right (dextrorsum volubilis). The leaves are facing each other, finger shaped, 2-5 indentations, jagged edges, pale green color. Sometimes it has two branches and each branch has two more branches. Fertile leaves are generally located at the tip of the plant and the edges of the leaves are more bumpy than sterile leaves (Dwiyanti et al. 2017). Sporangia are located on the lower surface of the fertile leaf (Holtum 1966; Shinta et al. 2012).

Observation of herbarium specimens in Herbarium Bogoriense, Botany Division, Research Center for Biology, Indonesian Institute of Science (LIPI), Bogor, Indonesia indicated that this fern is distributed in various regions in Indonesia including Sumatra, Java, Kalimantan, the Lesser Sunda Islands, Sulawesi, Maluku and Papua New Guinea; and its habitat ranges from the coast, rocky land, open land, marginal/poor soil nutrient forest, secondary forest, tropical forest, lowland forest, and dipterocarpa hill forest; at an altitude of 2-1,350 m above sea level. Thus, it may be concluded that this species grows in different ecosystems and does not require any special habitats for growth.

The older herbarium collections of this species (Figure 2) deposited in BO, among others, were collected from Java by Teysman (1854), Dr. Scheffer (1870), Dr. Scheffer (1871), Buck \& Marchy (1892), Hallier (1893), and Amdjah (1898). The use of this species has been recorded as a vegetable material (its young leaves), in the herbarium specimen.
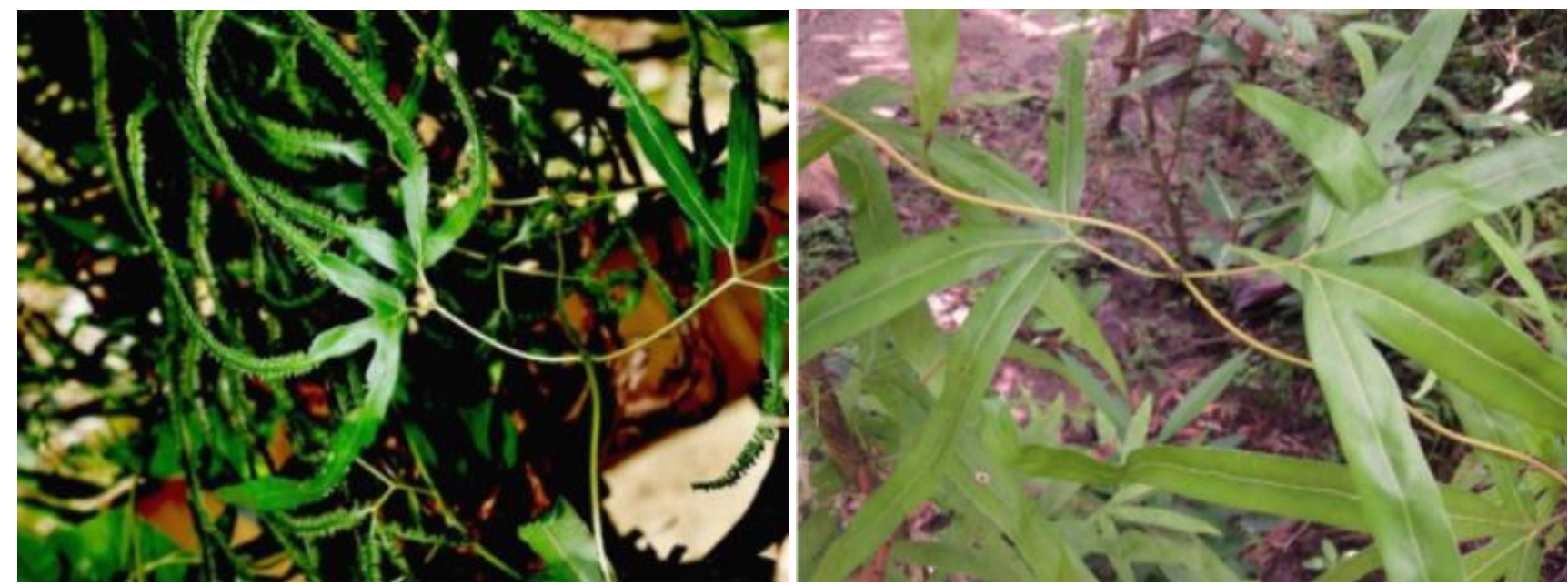

Figure 1. Lygodium circinnatum (Burm.f.) Swartz with wiry rachis 

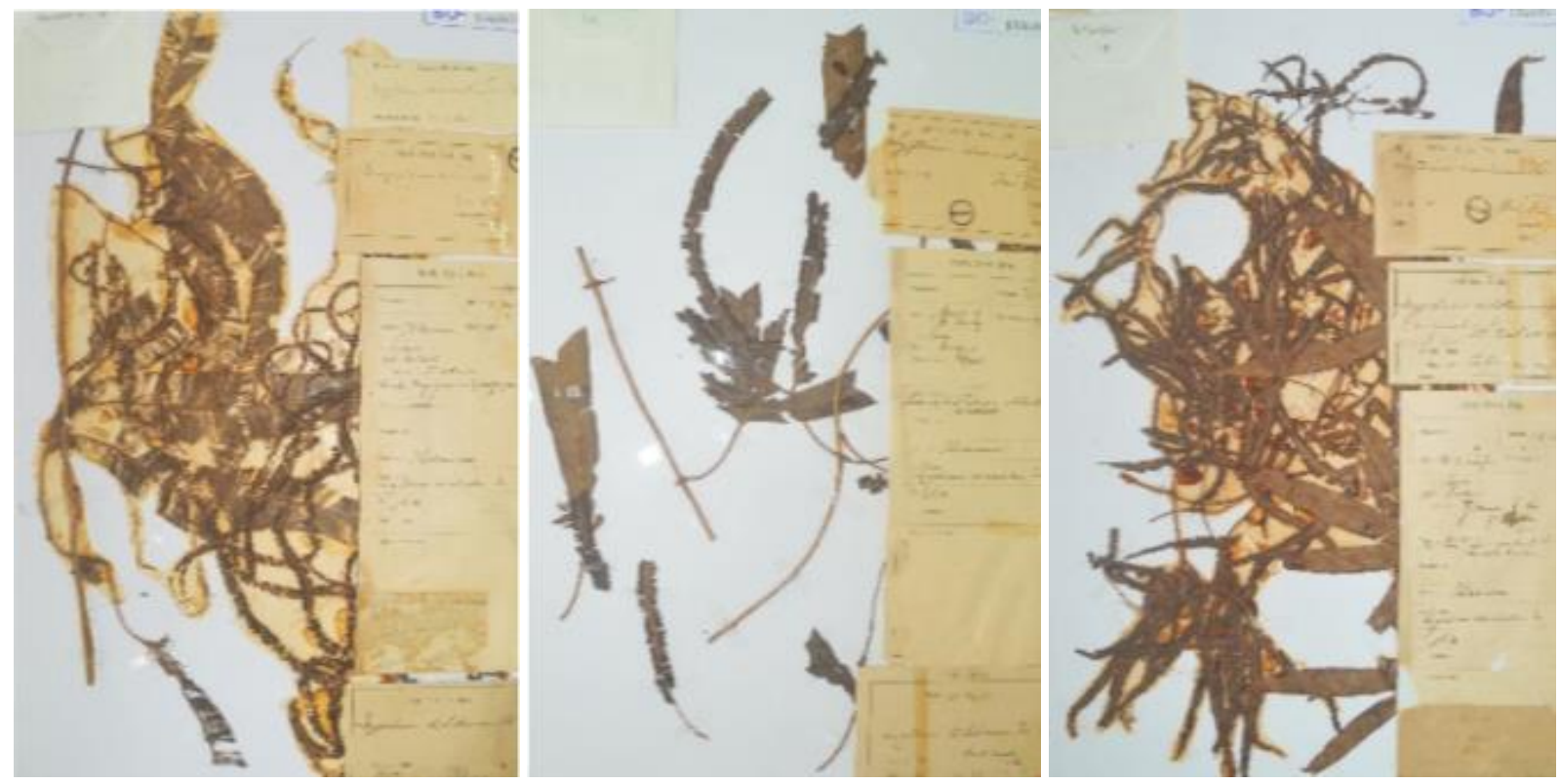

Figure 2. Specimens of Lygodium circinnatum deposited in Herbarium Bogoriense

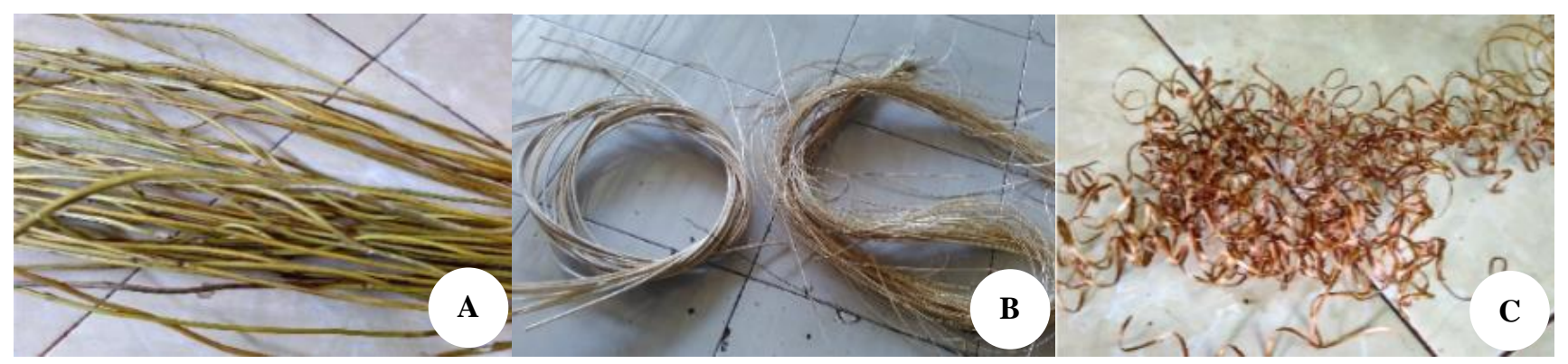

Figure 3. Preparing Lygodium circinnatum stem for weaving purpose. A. Leaves and twigs; B. The inner bark; C. Bark or pendaos (local name)
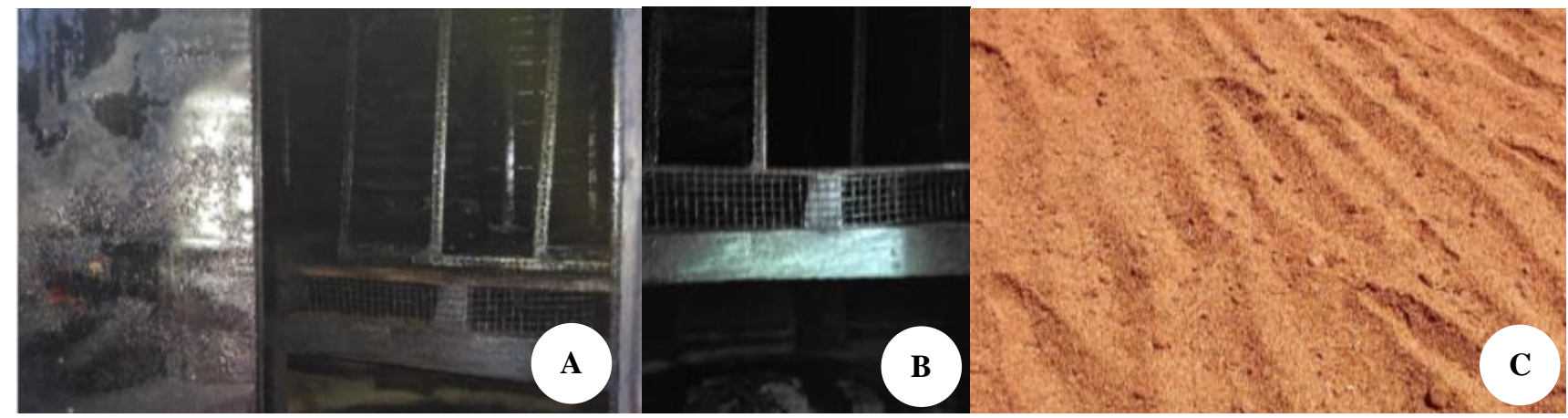

Figure 4. Lygodium circinnatum drying system and wood powder used for drying. The purpose is to ensure that they are not hard and rigid when weaving. A. The woven artefacts are heated in the oven; B. Arranged standing artefacts in the oven; C. Sun-dried wood powder used to burning artefacts

Various ethnomedicinal uses have been reported from different regions. According to Praptosuwiryo (2003), in Malaysia, the young leaves of $L$. circinnatum are used as a postpartum medicine; and exudate from rhizome as insect repellent and to treat aquatic animal and snake bites
(Hanum and Nurulhuda 1999). In New Gunea, it is used as a birth control drug and in the Philippines, a tapel from crushed leaves is used to cover the wounds. In Indonesia, the squeezed leaves are applied to injured area to neutralize the effect of poisonous animal bites. The leaves are also 
crushed with the rhizome of Curcuma sp. and are applied as a sprain medicine. Among the other traditional uses, the bark is used as a rope material (Heyne 1987). All parts of this plant are used in rice planting ceremonies in Sumatra (LBN-LIPI 1979).

Literature analysis related to the nutritional content and active compounds of this plant leaf that acts both as a vegetable and traditional medicine indicated that such studies are very limited. Research conducted by Riana et al (2017) found that Lygodium circinanntum contains phenolic and flavonoid active compounds with flavonoid content is higher than phenolic. This is in line with research conducted by Lai and Lim (2011), which revealed that the antioxidant compound Lygodium circinanntum was lower than compound of the other species such Cyathea latibrosa, Cibatium barometez, Drymaria quercifolia, Blechnum orientale and Dycranopteris linearis. Yamautchi et al. (1996) stated that this species contains antheriodogen compounds. Antheridiogens are chemicals released by the gametophytes that control the sex ratio in the plant by inducing the formation of male organ, the antheridium, in ferns (Tanaka et al. 2014).

From the descriptions given above, it may be known that $L$. circinnatum is not only a raw material for woven crafts, but also used as a vegetable ingredient, herbal medicine and have religious value as it is one of the plants used in the traditional rice planting ceremony.

The weaving of L. circinnatum had actually begun for daily household needs. However, with design guidance from the government, these "pengulat" craftsmen are able to produce various kind of products with different designs and styles thus adding value to this practice. Conventionally, L. circinnatum was woven into a variety of handicrafts such as trays, tissue boxes, containers of various sizes, boxes for wedding delivery, and bags.

The stages of weaving of L circinnatum are as follows: selection of L. circinnatum stems which are not too old and have been cleaned of leaves and twigs (Figure 3.A), the bark is peeled off the stem to separate the inner stem
(Figure 3.B), and the "pendaos" (Figure 3.C). The inner stem is used as "reinforcing material" of the artefact to be formed. "Pendaos" and the inner stem are dried for 3-4 days so that they are not easily attacked by fungi. Before weaving the "reinforcing material" to the desired shape of the craft, pendaos are soaked in water for about 1-2 hours. The purpose is to ensure that they are not hard and rigid when weaving. Artefacts thus woven are then heated in the oven (Figures 4.A-B) for about 2 days and 2 nights. This is to completely dry them to prevent attack by fungi or fleas. Also, a brown color is formed by drying which looks brighter. Burning material used to heat the oven is sundried wood powder (Figure 4.C).

The interviews conducted with "pengulat" weaving craftsmen indicated that the $L$. circinnatum stem raw material used were obtained mainly from Kalimantan, Sumbawa and Pangandaran. L. circinnatum plants grow wild in these areas and are collected from the forests. Earlier to 1980, L. circinnatum ferns were also found in the island of Lombok. However, because their collection was carried out continuously and excessively without any effort to cultivate, L. circinnatum population is rarely found here, at present. Especially since 1986, L. circinnatum weaving intensified in the island of Lombok. The diverse products of L. circinnatum handicrafts (Figure 5) from the Beleke Village were mostly sold to Bali. As the variety of $L$. circinnatum products is not as much as from Lombok, sthe products of Kendari are traded mainly at "Dekranasda" National Crafts Council in Kendari area. L. circinnatum handicrafts also has potential export markets abroad, in countries such as Germany, France, Britain and Japan (Dinas Perindustrian dan Perdagangan 2010).

Lygodium circinnatum is a species plant of economic value as a producer of non-wood forest products in the form of handicraft raw materials. However, there are no detailed data on the size and potential distribution of the population as raw material for industry experiencing significant obstacles (Wahyuningsih et al. 2017).

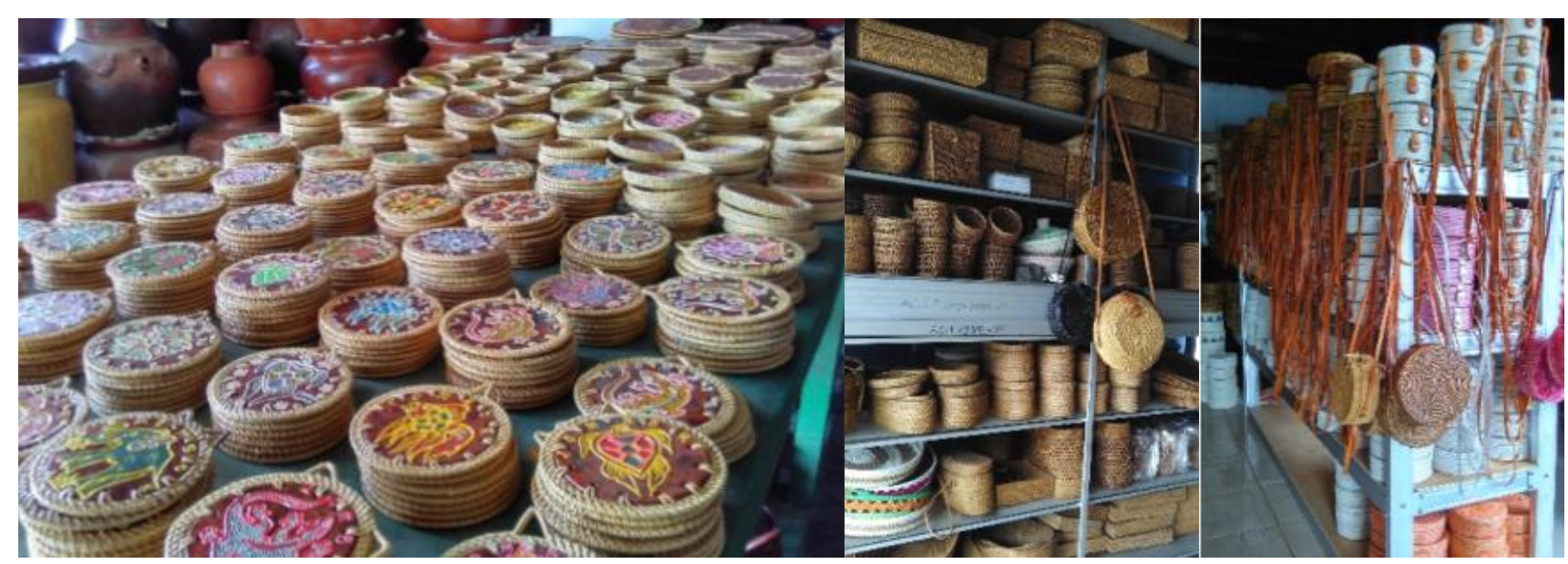

Figure 5. Products made from Lygodium circinnatum 
Lygodium circinnatum can be cultivated in two ways, generatively by germinating spores and vegetatively by dividing saplings or adventitious shoots. Propagation by spores require a relatively longer time, however it can produce more plants than by vegetative propagation. The success of this method is influenced by many factors, such as spore maturity, planting media and environmental conditions (Siregar et al. 2014). Propagation of $L$. circinnatum can also be done in a more modern way by tissue culture technique. This method can produce more $L$. circinnatum plants in a relatively short period of time. Generally, the explants used are spores (Siregar et al. 2014; Dwiyanti et al. 2017).

As with the local woven handicraft industry, several factors inhibit woven handicrafts in Indonesia (Razak \& Elyta, 2017). The similar condition are also experienced in L. circinnatum handicrafts in this study, such as the pattern of thinking of local people who are less innovative due to the lack of educational and fostering institutions, marketing productivity of handicraft products, and availability raw materials are increasingly rare.

\section{REFERENCES}

Cunningham AB. 2001. Applied Ethnobotany: People, Wild Plant Use \& Conservation. Earthscan Publication. London.

Darmayanti AS. 2014. Fiber Producing Plant in Tahura Nipa-Nipa, Southeast Sulawesi. Proceeding in National Symposium. Inovas Teknologi Serat Alam, Balai Penelitian Tanaman Pemanis dan Serat, Malang. [Indonesian]

Dinas Perindustrian dan Perdagangan. 2010. Rekapitulasi Sentar Industri Kecil Menengah Propinsi Nusa Tenggara Barat, Mataram. [Indonesian]

Dwiyanti R, Yuswanti H, Darmawati IAP, Mayadewi NYA, Sukewijaya IM. 2017. Domestication of ferns: Lygodium circinnatum (Burm.f.) Sw. Pelawa Sari, Denpasar. [Indonesian]

Gusmawarni R, Sudarmawan, A, SurAtin L. 2019. Rattan weaving craft in Beleka Village, Central Lombok. Jurnal Pendidikan Seni Rupa Undiksha 9 (2): 58-68. [Indonesian]

Hanum IF, Nurulhuda H. 1999. The Use of Medicinal Plant Species by Temuan Tribe of Ayer Hitam Forest, Selangor, Peninsular Malaysia. J Trop Agric Sci 22 (2): 85-94.

Hasibuan H, Rizalinda, Rusmiyanto PWE. 2016. Inventory of fern species (Pteridophyta) in the Forest of Sungai Ambawang District, West Kalimantan. Jurnal Protobiont 5 (1): 48-58. [Indonesian]
Heyne K. 1987. Tumbuhan Berguna Indonesia. Badan Litbang Departemen Kehutanan \& Yayasan Sarana Wana Jaya, Jakarta. [Indonesian]

Holtum RE. 1966. A Revised Flora of Malaya. Fern of Malaya. Government Printing Office, Singapura.

Lai HY, Lim YY. 2011. Antioxidant Properties of Some Malaysian Ferns. IPCBEE 20: 8-12.

LBN-LIPI. 1979. Ferns. Lembaga Biologi Nasional-LIPI. CV Bina Karya, Bogor. [Indonesian]

Madeira PT, Pemberton RW, Center TD. 2008. A molecular phylogeny of the genus Lygodium (Schizaeaceae) with special reference to the biological control and host range testing of Lygodium microphyllum. Biol Control 45: 308-318.

Martin GJ. 1998. Etnobotany: A Method Manual Chapman \& Hall. London.

Praptosuwiryo TN. 2003. Lygodium Swartz. In: de Winter WP, Amoroso VB (eds.). Plant Resources of South-East Asia No. 15 (2) Cryptogams: Ferns and Fern Allies. PROSEA, Bogor, Indonesia.

Razak A, Elyta. 2017. The resestor factors of handicrafts in Sajingan Besar border againts ASEAN Economic Community. Sosiohumaniora 19 (3): 213-217.

Riana BAS, Mokhtar RAM, Iqbal M. 2017. Identification of bioactive compound, quantitatiive measurement of phenolic and flavonoid contented and radical scavenging activity of Lygodium circinnatum. Trans Sci Technol 4 (3-3): 354-359.

Rice J. 2016. Profesional purity: Revolutionary writing in the craf beer industry. J Bussiness Technol Commun 30 (2): 236-261.

Rugayah, Sunarti S, Sulistiarini D, Hidayat A, Rahayu M. 2015. List of Plant Species on Wawonii Island, South Sulawesi. LIPI Press, Jakarta. [Indonesian]

Shinta RN, Arbain A, Syamsuardi. 2012. The morfometrics study of climbing fern (Lygodium) in West Sumatra. Jurnal Biologi Universitas Andalas 1 (1): 45-53. [Indonesian]

Siregar HM, Darma DP, Lestari WS. 2014. Fern of Lygodium circinnatum (Burm.f.) Sw.: Cultivation \& Prospects. Eka Karya Bali Botanic Garden, LIPI, Tabanan. [Indonesian]

Suyarno. 2019. Hata Non-timber Forest Products Management as Craft Raw Materials in Cimatupang, Pangandaran District, Potential that must be sustainable. Dishut Jabar Edisi 74. http://dishut.jabarprov.go.id/index3.php?mod=detailArtikel. [Indonesian]

Tanaka J, Yano K, Aya K, Hirano K, Takehara S, Koketsu E, Ordonio RL, Park SH, Nakajima M, Ueguchi-Tanaka M, Matsuoka M. 2014. Antheridiogen determines sex in ferns via a spatiotemporally split gibberellin synthesis pathway. Science 346 (6208): 469-473.

Wahyuningsih E, Faridah E, Budiadi. 2017. Plant species for ketak's growth (Lygodium circinnatum (Burm.f.) Sw.) in Lombok Island Nature Reserve, NTB. Jurnal Sangkareang Mataram 3 (2): 16-19. [Indonesian]

Yamauchi T, Oyama N, Yamane H, Murofushi N, Schraudolf H, Pour M, Furber M, Mander LN. 1996. Identification of antheridiogens in Lygodium círcinnatum and Lygodium flexuosum. Plant Physiol 11(1): 741-745. 